\title{
Comparative analysis of information seeking behaviour among students of Babcock University, Nigeria
}

\author{
Onuoha, Uloma Doris \& Obiako, Angela Ndubumna
}

\begin{abstract}
The study investigated the information seeking behaviour of students of Babcock University. The major objective was to compare the information seeking behaviour of first and final students. The descriptive research approach was used for the study. The population was made up of 3,684 undergraduate students. Study sample were selected using multistage sampling technique. A sample size of 354 was obtained. A self designed questionnaire was used for data collection. Data collected was analysed using descriptive statistic such as frequency counts and simple percentage. Findings revealed that first and second year students, had similar reasons for seeking information. Both groups of student (first and final year) were also found to have similar preference for information materials. Corresponding agreement was also seen in the area of problems encountered when using the university library. The study concludes by noting that there is no significant difference in the information seeking behaviour of first and final year students of Babcock University. The study, however, recommends amongst others, that the university library carry out occasional staff training that would enable staff see the importance of assisting users in order to eliminate some of the problems faced by students when using the library.
\end{abstract}

Keywords: Babcock University, Information needs, Information seeking behaviour.

Submitted Date 29 May 2013

Accepted Date: 04 June 2013

\section{Introduction}

Information, has been described by Gordon (1994) as the human understanding that steers action. Uttor (1999), however, gives a more comprehensive definition of information as data that has been subjected to some processing functions capable of answering user's query, be it recorded, summarized, or simply collected that would help decision making. Information could, therefore, be in form of communication or recorded knowledge which when interacted with could be understood in a way that the state of a recipients' knowledge is transformed. Information use by undergraduates is, however, prompted mostly by academic needs met through the use of information resources such as books, journals, public and private sector documents of all kinds, results of research made available in print and electronic formats. Considering the rapid changes in information provision in the 21 st Century with computerized access, digitized information formats, and the excess of resources on the Internet, the importance of information seeking and associated behaviour of the seeker cannot be overemphasised, hence, this study therefore seeks to investigate undergraduate students information seeking behaviour at Babcock University.

\section{Background of Babcock University}

Babcock University is a private Christian University owned and operated by the Seventh-day Adventist Church. The University is located between Ibadan and Lagos. Babcock University academic programmes are structured into four schools which include the school of Education And Humanities, School of Law and Security Sciences, School of Management and Social Sciences and the School of Science and Technology.

\section{Statement of the problem}

Information has always been a vital resource required by students in their academic pursuit. While students depended so much on libraries in the past for information, advancement in technology has given rise to proliferation of information in various sources, thereby, creating a need to identify the information seeking behaviour of undergraduates. It is in the light of this that the present study seeks to compare the information behaviour and first and final year students at Babcock University.

The objectives of the study are:

1. To identify the information needs of first and final year students of Babcock University

2. To examine the preferred sources of obtaining information by first and final year students

3. To identify the problems encountered by first and final year students of Babcock University while using the library. 
Comparative analysis of information seeking behaviour among students of Babcock University,

\section{Scope of the study}

This study is limited to first and final year students of Babcock University. The choice of using first year students is based on the fact that they have just joined the university community while final year students were chosen on the basis that they have spent at least three years within the university environment, hence, are likely to manifest different patterns of information seeking behaviour.

\section{Review of literature}

Information needs is an aspect of information behaviour that represents the root of information search behaviour (Wilson, 2000). A person seeks information to satisfy his or her information needs. Information needs is understood in information science as stemming from a vague awareness of something missing and as culminating in locating information that contributes to understanding and meaning (Kuhlthau, 1993). It is an anomalous state of knowledge (Belkin, Brooks and Oddy, 1982), or a gap in individual's knowledge in sense making situations (Dervin and Nilan, 1986). From the definitions it can be deduced that information need is a result of an intense desire to acquire knowledge in order to reduce gap in knowledge.

Fidazani (1998) conducted a study at University of Botswana, and findings from the study revealed that students rely on library books, textbooks, and journals. Kakai, Ikoja-Odongo, and Kigongo-Bukenya (2004) researched on the information-seeking behaviour of undergraduate students of Makerere University, Uganda, and discovered that the students rely on textbooks as their major source of information. Chikonzo and Aina (2006) researched primarily into the information needs and sources of information used by veterinary students at the University of Zimbabwe. Findings from the study revealed that writing assignments and studying for tests or examination were the primary tasks for which they required information and the major sources used to obtain information were books, videos, lecture notes, handouts, the internet, projects, CD-ROM database and journals.

Okiki and Asiru (2009) affirmed that students offering correspondence course all over Africa have the benefit of the use of e- mail and World Wide Web to obtain advice and reading material from their tutors. Onuoha and Awoniyi (2011) compared the information seeking behaviour of students at Babcock University, Nigeria and Solusi University, Zimbabwe. Findings from the study revealed that students in both universities sought information mainly for the purpose of updating their knowledge, preparing for examinations and doing assignments.

Barriers to information seeking are highlighted by INFORSS study conducted by Bath University (1971). Barriers to information seeking were found to include: inadequate library facilities, insufficient time for research, and insufficient opportunities for informal exchange of information. Matheson (1979) in a similar study also identified time to look for and read information as a major problem among students seeking information. Harris and Dewdney (1994) found barriers to information seeking to include: not knowing what information is needed; not knowing where to find the information that one realizes is needed and lack of awareness of the existence of resources for information. Taylor (1990) also points out that after interacting with the information sources (like in a library) what a user actually needs may not tally with what is practically available due to constraint either within the stock or due to the users own inability. In a most recent study, Onuoha and Awoniyi (2011) identified obsolete materials as the major source of problem identified by students when seeking information in libraries.

\section{Research methodology}

The descriptive survey design was used for the study. The study population comprises of 3,684 first and final year undergraduate students in Babcock University. Multistage sampling technique was used for selecting respondents. This was done by first stratifying respondents according to faculties, after which simple random sampling was used to select two faculties. Simple random sampling technique was used to select six departments from the two faculties. Thereafter, proportional random sampling technique was used to select $28 \%$ of the students from the selected departments. A sample size of 354 was obtained. A self designed questionnaire was used for data collection. Data collected was analysed using descriptive statistic such as frequency counts and simple percentage. A break down of the selected faculties, departments and sample size is shown in table 1 .

Table 1: Selected faculties, departments and sample size

\begin{tabular}{|l|l|l|l|l|l|}
\hline Selected faculties & $\begin{array}{l}\text { Selected } \\
\text { departments }\end{array}$ & \multicolumn{2}{|l|}{$\begin{array}{l}\text { Total number of } \\
\text { students }\end{array}$} & $\begin{array}{l}\text { 28\% of the total number of } \\
\text { students }\end{array}$ \\
\hline & & $\begin{array}{l}\text { First } \\
\text { year }\end{array}$ & $\begin{array}{l}\text { Final } \\
\text { year }\end{array}$ & First year & Final year \\
\hline $\begin{array}{l}\text { Science } \\
\text { Technology }\end{array}$ & 3 & 44 & 1 & 12 \\
& $\begin{array}{l}\text { - Nursing } \\
\text {-Agriculture }\end{array}$ & 13 & 26 & 4 & 7 \\
\hline
\end{tabular}


Comparative analysis of information seeking behaviour among students of Babcock University,

\begin{tabular}{|l|l|l|l|l|l|}
\hline & and Mathematics & & & & \\
\hline $\begin{array}{l}\text { Babcock Business } \\
\text { School }\end{array}$ & $\begin{array}{l}\text { Banking and } \\
\text { Finance } \\
\text {-Mass } \\
\text { Communication } \\
\text {-Information } \\
\text { Resources } \\
\text { Management }\end{array}$ & 95 & 103 & 27 & 28 \\
\hline & Sub total & 80 & 29 & 35 \\
\hline & Total & $\mathbf{6 0 7}$ & $\mathbf{6 7 0}$ & $\mathbf{1 7 1}$ & $\mathbf{1 9 9}$ \\
\hline
\end{tabular}

Source: Babcock University Registry, Data and Archival Unit, 2012.

V. Presentation Of Result

Table 2: Demographic characteristics of respondents

\begin{tabular}{|c|c|c|c|c|}
\hline \multicolumn{2}{|l|}{ Characteristics } & $\begin{array}{l}\text { FIRST YEAR } \\
(\mathbf{n}=171)\end{array}$ & $\begin{array}{l}\text { FINAL } \\
\text { YEAR } \\
\quad(n=183)\end{array}$ & $\begin{array}{l}\text { TOTAL } \\
(\mathbf{3 5 4})\end{array}$ \\
\hline \multirow{4}{*}{ Gender } & \multirow{2}{*}{ Female } & 87 & 97 & 184 \\
\hline & & $50.8 \%$ & $52.9 \%$ & $51.9 \%$ \\
\hline & \multirow{2}{*}{ Male } & 84 & 86 & 170 \\
\hline & & $49.2 \%$ & $47.1 \%$ & $48.1 \%$ \\
\hline \multirow{4}{*}{ Name of Faculty } & \multirow[t]{2}{*}{ SAT } & 97 & 88 & 185 \\
\hline & & $56.3 \%$ & $48.1 \%$ & $52.2 \%$ \\
\hline & \multirow[t]{2}{*}{ BBS } & 74 & 95 & 169 \\
\hline & & $43.7 \%$ & $51.9 \%$ & $47.8 \%$ \\
\hline
\end{tabular}

Out of 370 copies of the questionnaire distributed, 354 were successfully retrieved. This gave a response rate of 97\%. Findings in Table 2 reveals that 170 (48.1\%) were male while $184(51.9 \%)$ were female. The gender and faculty distribution are almost equally represented. Out of the total number of 187 undergraduates in the faculty of Science and Technology (SAT), 97 (56.3\%) are first year students and 88 (48.1\%) are final students. The 165 students of Babcock Business School (BBS) share a number of 74 (43.7\%) for first year students and $95(51.9 \%)$ for final year students.

Table 3: Information needs of first and final year undergraduate students.

\begin{tabular}{|c|c|c|c|c|}
\hline \multicolumn{2}{|c|}{ What is your purpose for seeking information? } & \multirow{2}{*}{$\begin{array}{l}\text { FIRST } \\
\text { YEAR } \\
137 \\
\end{array}$} & \multirow{2}{*}{$\begin{array}{l}\text { FINAL YEAR } \\
150\end{array}$} & \multirow{2}{*}{$\begin{array}{l}\text { TOTAL } \\
287 \\
\end{array}$} \\
\hline $\mathbf{A}$ & For improving general knowledge & & & \\
\hline & & $74.9 \%$ & $80.2 \%$ & $77.6 \%$ \\
\hline \multirow[t]{2}{*}{$\mathbf{B}$} & \multirow{2}{*}{ For doing assignment } & 125 & 109 & 234 \\
\hline & & $68.3 \%$ & $58.3 \%$ & $63.2 \%$ \\
\hline \multirow[t]{2}{*}{$\mathbf{C}$} & \multirow[t]{2}{*}{ For exam preparation } & 116 & 117 & 233 \\
\hline & & $63.4 \%$ & $62.6 \%$ & $63.0 \%$ \\
\hline \multirow[t]{2}{*}{$\mathbf{D}$} & \multirow[t]{2}{*}{ For writing term paper and presentation } & 101 & 108 & 209 \\
\hline & & $55.2 \%$ & $57.8 \%$ & $56.5 \%$ \\
\hline \multirow[t]{2}{*}{$\mathbf{E}$} & \multirow[t]{2}{*}{ For quiz/test } & 68 & 45 & 113 \\
\hline & & $37.2 \%$ & $24.1 \%$ & $30-5 \%$ \\
\hline \multirow[t]{2}{*}{$\mathbf{F}$} & \multirow[t]{2}{*}{ For preparing class notes } & 54 & 54 & 108 \\
\hline & & $29.5 \%$ & $28.9 \%$ & $29.2 \%$ \\
\hline \multirow[t]{2}{*}{$\mathbf{G}$} & \multirow[t]{2}{*}{ For conference } & 39 & 28 & 67 \\
\hline & & $21.3 \%$ & $15.0 \%$ & $18.1 \%$ \\
\hline \multirow[t]{2}{*}{$\mathbf{H}$} & \multirow[t]{2}{*}{ For semester registration } & 19 & 21 & 40 \\
\hline & & $10.4 \%$ & $11.3 \%$ & $10.8 \%$ \\
\hline \multirow[t]{2}{*}{$\mathbf{I}$} & \multirow[t]{2}{*}{ For debate } & 9 & 12 & 21 \\
\hline & & $4.9 \%$ & $6.4 \%$ & $5.7 \%$ \\
\hline \multirow[t]{2}{*}{$\mathbf{J}$} & \multirow{2}{*}{$\begin{array}{l}\text { Others } \\
\text { (Please specify)............................ }\end{array}$} & 3 & 7 & 10 \\
\hline & & $1.6 \%$ & $3.8 \%$ & $2.7 \%$ \\
\hline
\end{tabular}


Comparative analysis of information seeking behaviour among students of Babcock University,

According to Table 3, both first and final year undergraduates need information mostly for improving knowledge as indicated by $137(74.9 \%)$ and $150(80.25 \%)$ of the respondents respectively and for doing assignment. The least reasons for seeking information were for the purpose of semester registration and debate. While the low need for information in the area of debate can be easily understood as most students do not necessarily engage in debates, it is, however, worrisome in the case of semester registration where it is presumed that students would need information to enable them register early and settle down for lectures. The findings are, however, in agreement with those of Onuoha and Damilola (2011); Chikonzo and Aina (2006) whose studies found out that updating knowledge and writing assignments were the primary reasons why students seek information.

Table 4: Preferred sources for obtaining information

\begin{tabular}{|c|c|c|c|c|}
\hline \multirow{2}{*}{\multicolumn{2}{|c|}{ What are your preferred sources for obtaining information? }} & \multirow{3}{*}{$\begin{array}{l}\text { FIRST } \\
158\end{array}$} & \multirow{3}{*}{$\begin{array}{l}\text { FINAL } \\
180\end{array}$} & \multirow{3}{*}{$\begin{array}{l}\text { TOTAL } \\
338\end{array}$} \\
\hline & & & & \\
\hline $\mathbf{A}$ & \multirow[t]{2}{*}{ Textbook (print) } & & & \\
\hline & & $86.3 \%$ & $96.8 \%$ & $91.6 \%$ \\
\hline $\mathbf{B}$ & \multirow[t]{2}{*}{ Newspaper } & 114 & 139 & 253 \\
\hline & & $62.3 \%$ & $74.7 \%$ & $68.6 \%$ \\
\hline $\mathbf{C}$ & \multirow[t]{2}{*}{ Magazines } & 82 & 64 & 146 \\
\hline & & $44.8 \%$ & $34.4 \%$ & $39.6 \%$ \\
\hline D & \multirow[t]{2}{*}{ Book review } & 40 & 52 & 92 \\
\hline & & $21.9 \%$ & $28.0 \%$ & $24.9 \%$ \\
\hline $\mathbf{E}$ & \multirow[t]{2}{*}{ Thesis/ Research Report (print) } & 37 & 37 & 74 \\
\hline & & $20.2 \%$ & $19.9 \%$ & $20.1 \%$ \\
\hline $\mathbf{F}$ & \multirow[t]{2}{*}{ e-Databases } & 43 & 24 & 67 \\
\hline & & $23.5 \%$ & $12.9 \%$ & $18.2 \%$ \\
\hline $\mathbf{G}$ & \multirow[t]{2}{*}{ Government publications } & 32 & 13 & 45 \\
\hline & & $17.5 \%$ & $7.0 \%$ & $12.2 \%$ \\
\hline $\mathbf{H}$ & \multirow[t]{2}{*}{ Annual reviews } & 23 & 20 & 43 \\
\hline & & $12.6 \%$ & $10.8 \%$ & $11.7 \%$ \\
\hline \multirow[t]{2}{*}{$\mathbf{I}$} & \multirow[t]{2}{*}{ Others } & 12 & 8 & 20 \\
\hline & & $6.6 \%$ & $4.3 \%$ & $5.4 \%$ \\
\hline
\end{tabular}

Table 4 shows the preferred sources of information for first and final year students of Babcock University. Generally, greater number of students $(338,91.6 \%)$ preferred printed textbooks for meeting their information need. Another source of information preferred by the students is newspaper as indicated by $253(68.6 \%)$ of the respondents. Annual reviews and Government publications were the least preferred sources of information. This may not be unconnected to the fact that students may not be carrying out assignments needing such documents. It may not also be out of place to assume that such documents may not be available in the university library. The findings are in agreement with the findings of Fidazani (1998) and Kakai, IkojaOdongo, and Kigongo-Bukenya (2004) whose studies revealed that students relied mainly on textbooks as their major source of information.

Table 5: Problems encountered while seeking information while using the library for information seeking.

\begin{tabular}{|c|c|c|c|c|c|c|c|}
\hline & & \multicolumn{3}{|c|}{ First year } & \multicolumn{3}{|c|}{ Final year } \\
\hline & Problems encountered & 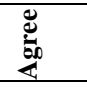 & : & 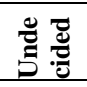 & 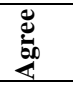 & 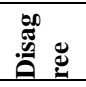 & 总 \\
\hline 1 & I don't know how to use the catalogue & $\begin{array}{l}27 \\
16.6 \%\end{array}$ & $\begin{array}{l}52 \\
31.9 \%\end{array}$ & $\begin{array}{l}84 \\
51.5 \%\end{array}$ & $\begin{array}{l}16 \\
8.9 \%\end{array}$ & $\begin{array}{l}41 \\
22.8 \%\end{array}$ & $\begin{array}{l}123 \\
68.3 \%\end{array}$ \\
\hline 2 & Library staff are unwilling to help in finding materials & $\begin{array}{l}17 \\
10.4 \%\end{array}$ & $\begin{array}{l}84 \\
51.5 \%\end{array}$ & $\begin{array}{l}62 \\
38.0 \%\end{array}$ & $\begin{array}{l}14 \\
7.8 \%\end{array}$ & $\begin{array}{l}72 \\
40.0 \%\end{array}$ & $\begin{array}{l}94 \\
52.2 \%\end{array}$ \\
\hline 3 & $\begin{array}{l}\text { The University library does not offer selective } \\
\text { dissemination service }\end{array}$ & $\begin{array}{l}17 \\
10.6 \%\end{array}$ & $\begin{array}{l}55 \\
34.4 \%\end{array}$ & $\begin{array}{l}88 \\
55.0 \%\end{array}$ & $\begin{array}{l}13 \\
7.5 \%\end{array}$ & $\begin{array}{l}41 \\
23.7 \%\end{array}$ & $\begin{array}{l}119 \\
68.8 \%\end{array}$ \\
\hline 4 & Information materials are obsolete & $\begin{array}{l}14 \\
8.6 \%\end{array}$ & $\begin{array}{l}37 \\
22.7 \%\end{array}$ & $\begin{array}{l}112 \\
68.7 \%\end{array}$ & $\begin{array}{l}7 \\
3.9 \%\end{array}$ & $\begin{array}{l}27 \\
15.0 \%\end{array}$ & $\begin{array}{l}146 \\
81.1 \%\end{array}$ \\
\hline 5 & Lack of time to search for information & $\begin{array}{l}11 \\
6.7 \%\end{array}$ & $\begin{array}{l}37 \\
22.7 \%\end{array}$ & $\begin{array}{l}115 \\
70.6 \%\end{array}$ & $\begin{array}{l}10 \\
5.6 \%\end{array}$ & $\begin{array}{l}26 \\
14.4 \%\end{array}$ & $\begin{array}{l}144 \\
80.0 \%\end{array}$ \\
\hline 6 & Materials are not available & $\begin{array}{l}10 \\
6.1 \%\end{array}$ & $\begin{array}{l}83 \\
50.9 \%\end{array}$ & $\begin{array}{l}70 \\
42.9 \%\end{array}$ & $\begin{array}{l}10 \\
5.6 \%\end{array}$ & $\begin{array}{l}127 \\
70.6 \%\end{array}$ & $\begin{array}{l}43 \\
23.9 \%\end{array}$ \\
\hline
\end{tabular}


Table 5 reveals the problem encountered while seeking for information by first and final year undergraduates. Majority of the respondents agreed that they do not know how to use the catalogue $53(25.5 \%)$ followed by library staff being unwilling to help in finding materials $31(18.2 \%)$. The least problems encountered were lack of time to search for information $21(12.3 \%)$ and materials not being available 20 $(11.7 \%)$.

The findings are in partial support of Harris and Dewdney (1994) who found barriers to information seeking to include not knowing what information is needed; not knowing where to find the information that one realizes is needed and lack of awareness of the existence of resources for information. The singular fact that 53 (25.5\%) agreed that not knowing how to use the library catalogue as a problem points to the fact that they may not know where to find the information they need. The findings, however, disagree with that of Onuoha and Awoniyi (2011) who identified obsolete materials as the major source of problem faced by students when seeking information in libraries.

\section{Discussion of findings}

From the findings, it is obvious that little difference exists in the information seeking behaviour of first and final year students at Babcock University. The respondents in this study, whether first or second year students, had similar reasons for seeking information. Most final and first year students sought information for improving general knowledge. Likewise, semester registration and debate were found to be the least reasons for seeking information by the two groups of students.

Both groups of student (first and final year) were also found to have similar preference for information materials. Printed textbooks were found to be preferred by both groups compared to all other sources of information, while government publications and annual reviews ranked lowest among the groups.

Corresponding agreement was also seen in the area of problems encountered when using the university library as both groups had similar percentages/frequency counts when agreeing to statements such as "I don't know how to use the catalogue" and "library staff are unwilling to help in finding materials".

\section{Conclusion}

The study sought to find out information seeking behaviour of first and final year students at Babcock University. Based on the findings, the study established that the information needs of both groups (first and final year students) are similar in nature as they need information basically to update general knowledge and for the purpose of carrying out class assignments. Both groups were also found to have a general preference for print books and newspapers as sources of information. In the case of problems encountered while using the library for information seeking, similar frequency counts were also observed. The study concludes, therefore, that there is no significant difference in the information needs, preference, and problems encountered in the use of the library among first and final year students in Babcock University.

\section{Recommendation}

Based on the findings the study recommends that:

1 University libraries should ensure adequate provision of print information sources, especially textbooks as students still prefer them to other sources of information.

2 Babcock university library, in particular, should make an effort to find out why students have low preference for government publications. This would aid the university library administration in decisions concerning the acquisition of such publications.

3 Babcock university library should also endeavour to train students in the use of the library's catalogue as not knowing how to use the library catalogue was identified as the most problem faced by students when using the library.

4 The university library (Babcock) should also carry out occasional staff training programmes that would enable staff see the importance of assisting users.

\section{References}

[1]. Bath University. (1971). Information requirements of College of Education lecturers and school teachers (Research Rep. No. 3 INFROSS). Bath: University of Bath Library.

[2]. Belkin, N.J., Brooks, H.M.,\& Oddy, R.N. (1982) ASK for information retrieval. Journal ofDocumentation. 38: 61-71

[3]. Chikonzo, A. C. \& Aina, L. O. (2006). Information Needs and Sources of Information Used by Veterinary Students at the University of Zimbabwe. Quarterly Bulletin International Association of Agricultural Information Specialists (IAALD), 46(1-2), 24-28

[4]. Dervin, B \& Nilan, M. (1986). Information needs and users. Annual Review of Information Science and Technology; 21: 3-33

[5]. Fidzani, B.T. (1998). Information needs and information-seeking behaviour of graduate at the University of Botswana. Library Review 47 (7): 329-340

[6]. Gordon, G. S. (1994). Some functions and properties of information. Journal of Information Science 20 (2):88-98.

[7]. Harris, R. M., \& Dewdney, P. (1994). Barriers to information: How formal help systems fail battered women. Westport, CT: Greenwood Press. 
Comparative analysis of information seeking behaviour among students of Babcock University,

[8]. Kakai M., Ikoja-Odongo, R., \& Kigongo-Bukeny I.M.N. (2004). A study of the information students of Makerere University, Uganda. World Libraries 14(1): 544-564.

[9]. Kuhlthau, C. (1993). Seeking Meaning: A Process Approach to Library and Information Services. Norwood, N.J. : Ablex.

[10]. Matheson, H. J. (1979). Information seeking behaviour and attitude towards information among education practitioners. Doctoral dissertation, University of British Colombia

[11]. Okiki, O. C. \& Asiru, S.M., (2009). Use of Electronic Information Sources by Postgraduate Students in Nigeria: Influencing Factors. Library Philosophy and Practice 30 (2): 135-151

[12]. Onuoha, U. D \& Awoniyi, A. A. (2011) Comparative Analysis of Students' Information Seeking Behaviour in Adventist Universities: A Survey of Babcock and Solusi Universities. Library Philosophy and Practice. Retrieved from http://unllib.unl.edu/LPP/onuoha-awoniyi.htm

[13]. Taylor, D.C.(1990). Undergraduates' use of periodicals: Implications for library reference Work. Reference Librarian, 12 (2728):51-65.

[14]. Uttor, J. (1999). The role of law libraries in democratic culture. A paper presented at the 1999 NLA National Conference and AGM. Aug $15^{\text {th }}-20^{\text {th }}$.

[15]. Wilson, T.D. (2000). Human Information Behaviour. Journal of Information science, 3(2), 49-55. 